\title{
IGLESIA DE SAN JERONIMO EL REAL. MADRID/ESPAÑA
}

\author{
(THE CHURCH OF SAN JERONIMO EL REAL. MADRID/SPAIN)
}

Francisco Jurado Jiménez, Arquitecto

Proyecto: $1985-1986$

Obras : En ejecución

\section{RESUMEN}

En este articulo se exponen las obras de restauración que se llevan a cabo en la iglesia de San Jerónimo el Real de Madrid.

A través de planos del proyecto, fotografias de las obras e, incluso, croquis de estudios preliminares, se revelan las circunstancias, patologia, problemas y soluciones que esta restauración conlleva.

\section{SUMMARY}

This article gives an exposition of the development of restoration works at San Jerónimo el Real in Madrid.

Through the plans of the project, photographs of the works and, even, sketches of the preliminaray studies it can be seen the circumstances, pathologies, problems and solutions inherent to this restoration.

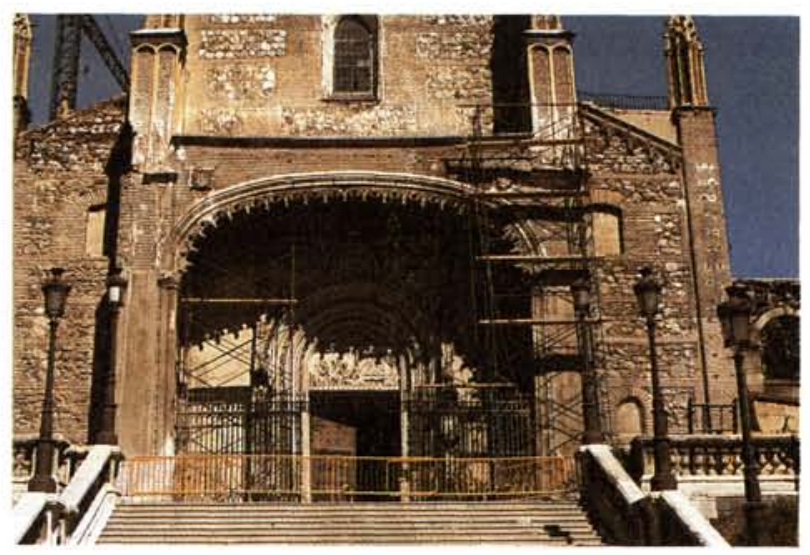

Entrada principal durante las obras.

La iglesia de San Jerónimo el Real pertenecía al antiguo Monasterio de los Jerónimos (s. XVI) -quizá se le conozca más por ese nombre-; quedó inscrita en el amplio conjunto del Palacio del Buen Retiro (mandado construir por Felipe IV en el siglo XVII), del que actualmente quedan trozos sueltos: Museo del Ejército, Casón del Buen Retiro y la propia iglesia con su claustro renacentista adosado.

En el año 1860 un importante desmonte en las calles deja el edificio exento y elevado respecto al Museo del Prado, perdiendo otro claustro anterior que poseía (el existente es

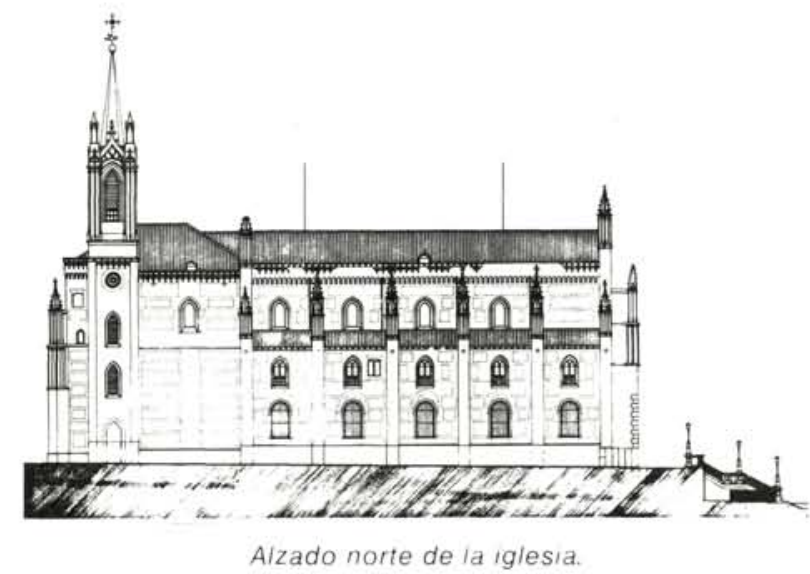

del siglo XVII, restaurado en 1783 por Juan de Villanueva y en 1962 por González Valcárcel).

En el siglo XIX es restaurada por Pascual y Colomer (que construye las dos torres) y, posteriormente, por el arquitecto diocesano Repullés, que busca una imagen neogótica del conjunto, al estilo de San Juan de los Reyes de Toledo.

Para los esponsales de Alfonso XIII se realiza la gran escalinata que conecta la plataforma del atrio con la calle. 


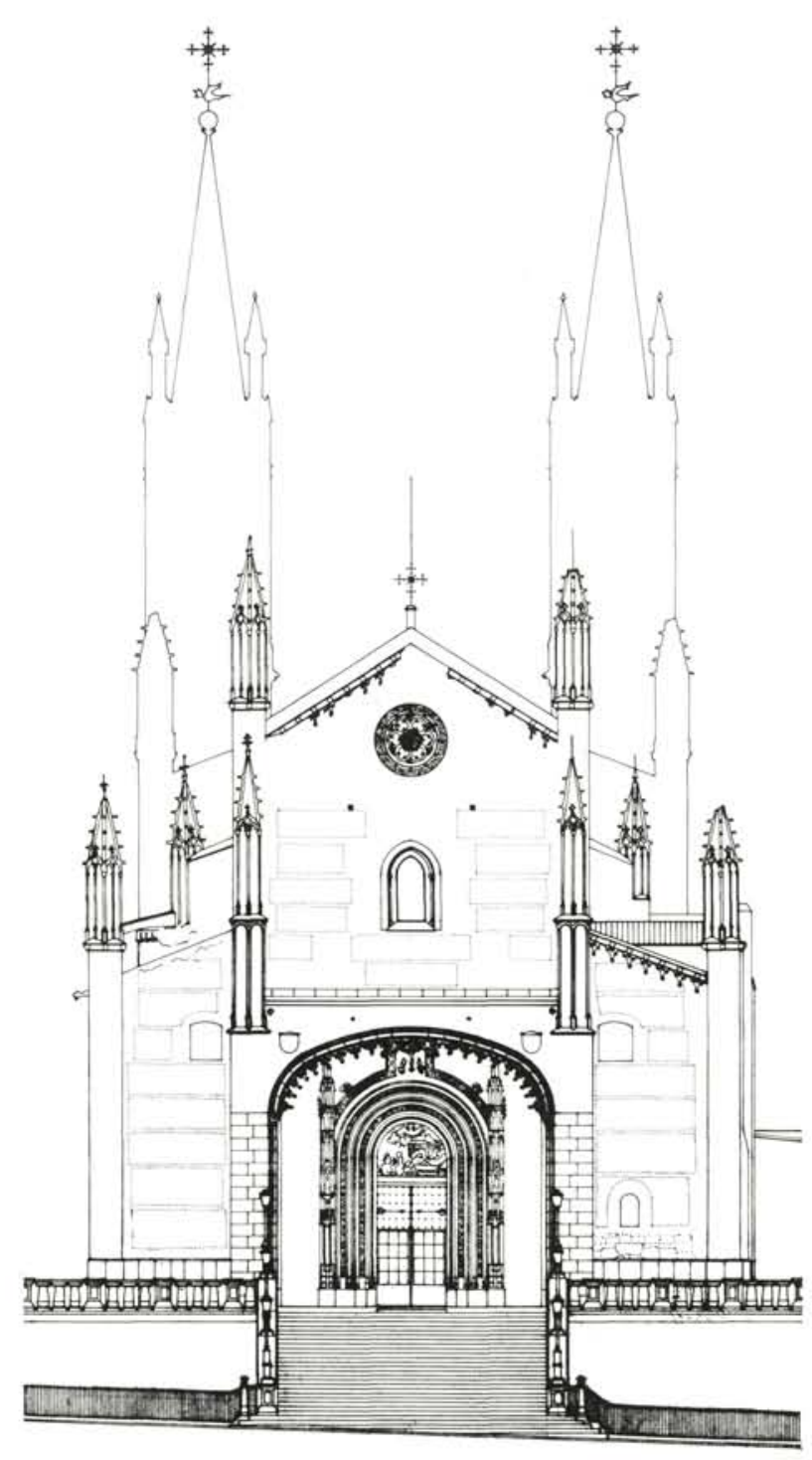

Alzado de la entrada principal.
En el año 1948, Francisco Iñiguez procede al picado de los revocos, quedando con el aspecto que actualmente conocemos de construcción toledana de fábricas de ladrillo de tejar con llaga a punta de paleta y mampuestos de piedra entre verdugados de ladrillo.

Al margen de las transformaciones que ha ido sufriendo el conjunto a lo largo de los años: pérdida del claustro anterior, añadido de las torres en el siglo XIX, etc., podemos reconstruir un cierto proceso patológico reciente.

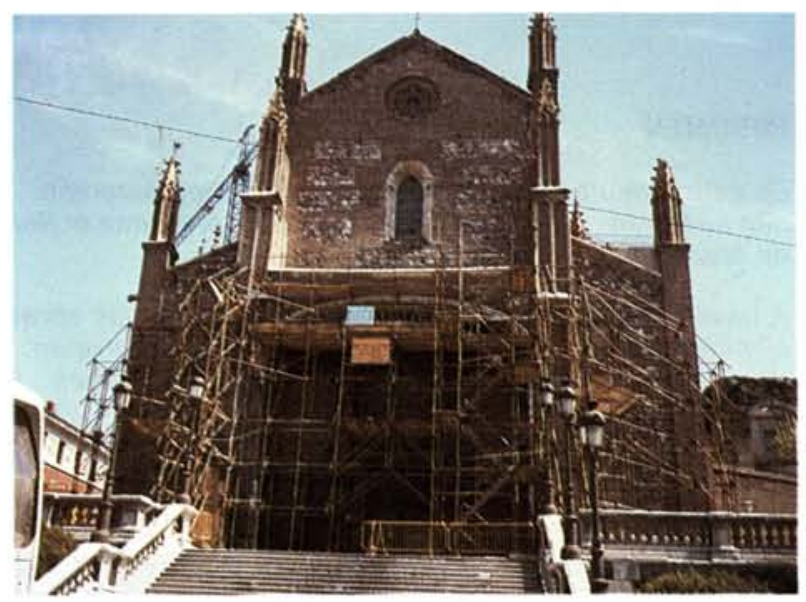

Apeo de todo el conjunto de bóveda y contrafuertes de la entrada principal (verano de 1985).

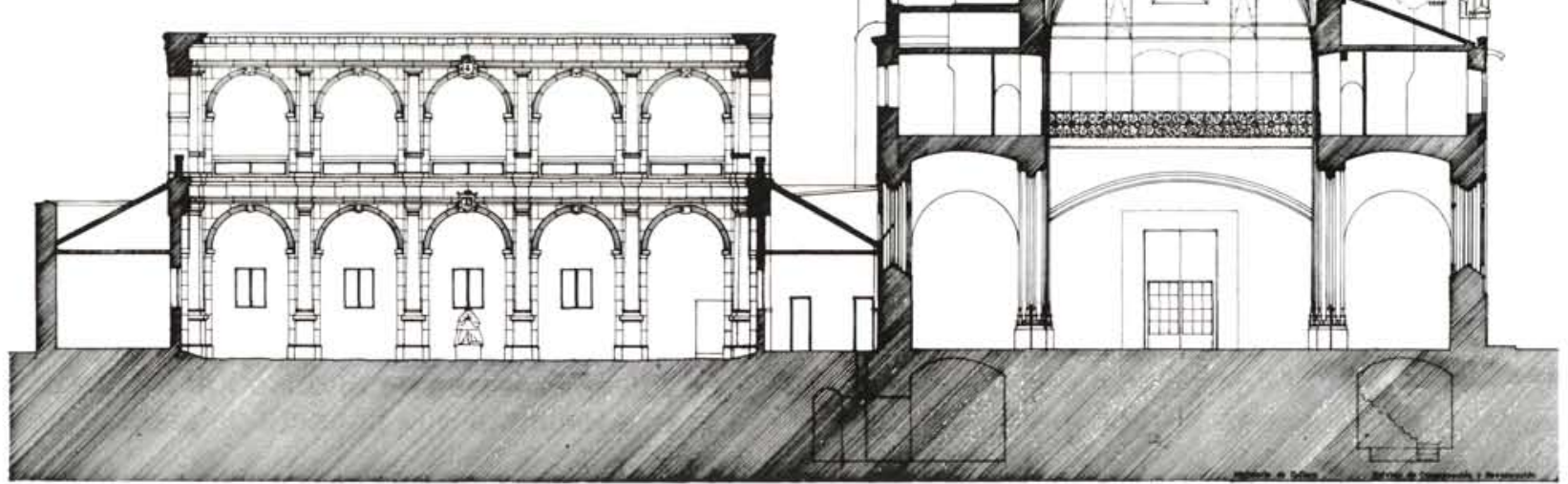




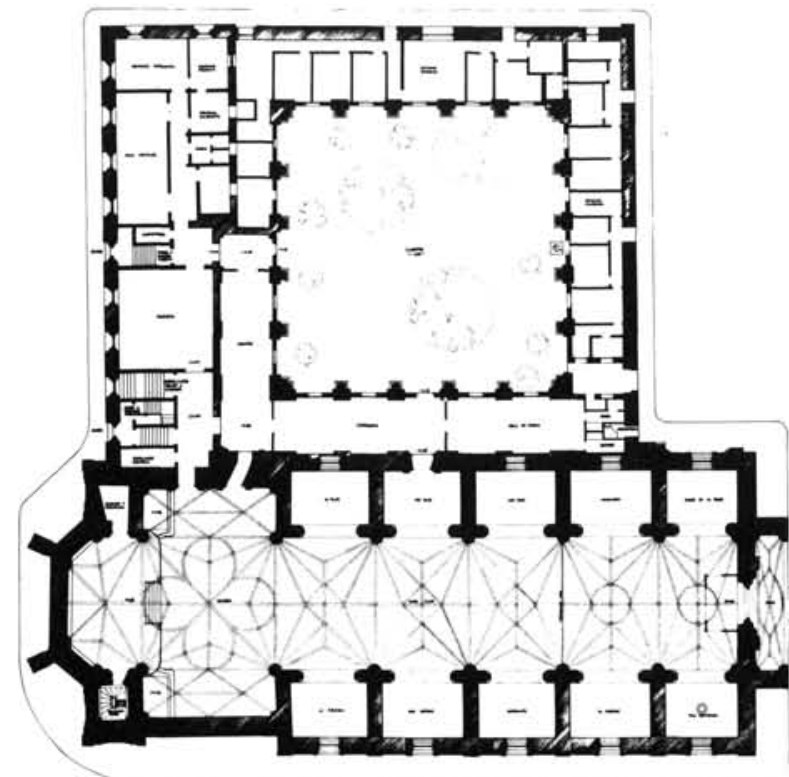

Planta del conjunto

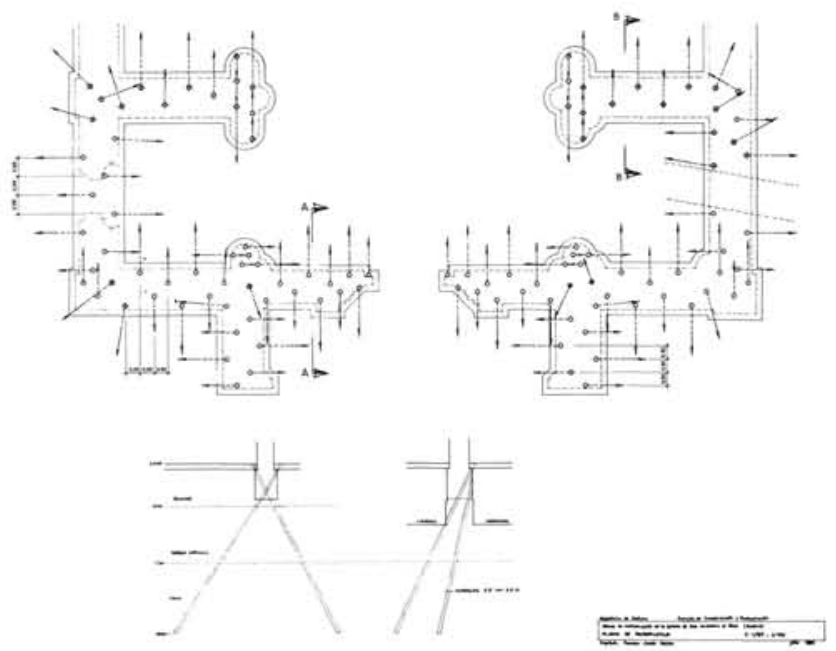

Planta de micropilotaje de la zona de entrada.

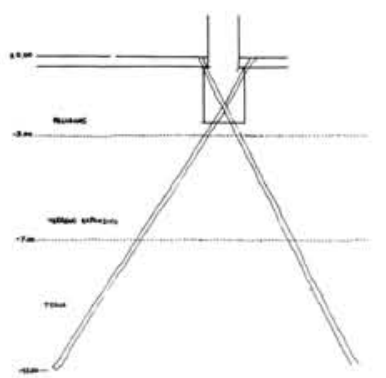

Detalle de las capas de terreno atravesadas por los micropilotes.
Repullés construyó unos arbotantes de ladrillo en la fachada norte, porque los pináculos se le inclinaban hacia el interior.

También se pueden observar grapas metálicas que intentan "coser» grietas entre los machones de la bóveda de la portada y el resto de los muros, así como tirantes metálicos "atando" la fábrica encima del arco carpanel con el muro de la portada, otros tirantes metálicos completamente desprendidos intentando sujetar el piñón de la cubierta con los muros laterales, tirantes de madera en diagonal uniendo la base de los pináculos laterales del arco carpanel con el muro de la portada, etcétera.

Todos estos elementos denotan que siempre ha habido un problema de despegue de la cubierta de la portada (seguramente un añadido al resto, al menos la actual) respecto del cuerpo principal de la iglesia.

Es, sin embargo, en el verano de 1984 cuando esta bóveda y sus machones base, que protejen la entrada principal, entran en un proceso de ruina acelerado: el arco se abre y el conjunto de bóveda y machones parece poder volcarse sobre la escalinata.

Tras el apeo apresurado de la portada se realiza un estudio geotécnico, del que parece desprenderse que la iglesia se asienta sobre terreno ligeramente expansivo y que una probable fuga de un colector, que pasa por el atrio, ha provocado cambios en el contenido de humedad del terreno y el consiguiente movimiento de despegue de la bóveda y sus apoyos. 


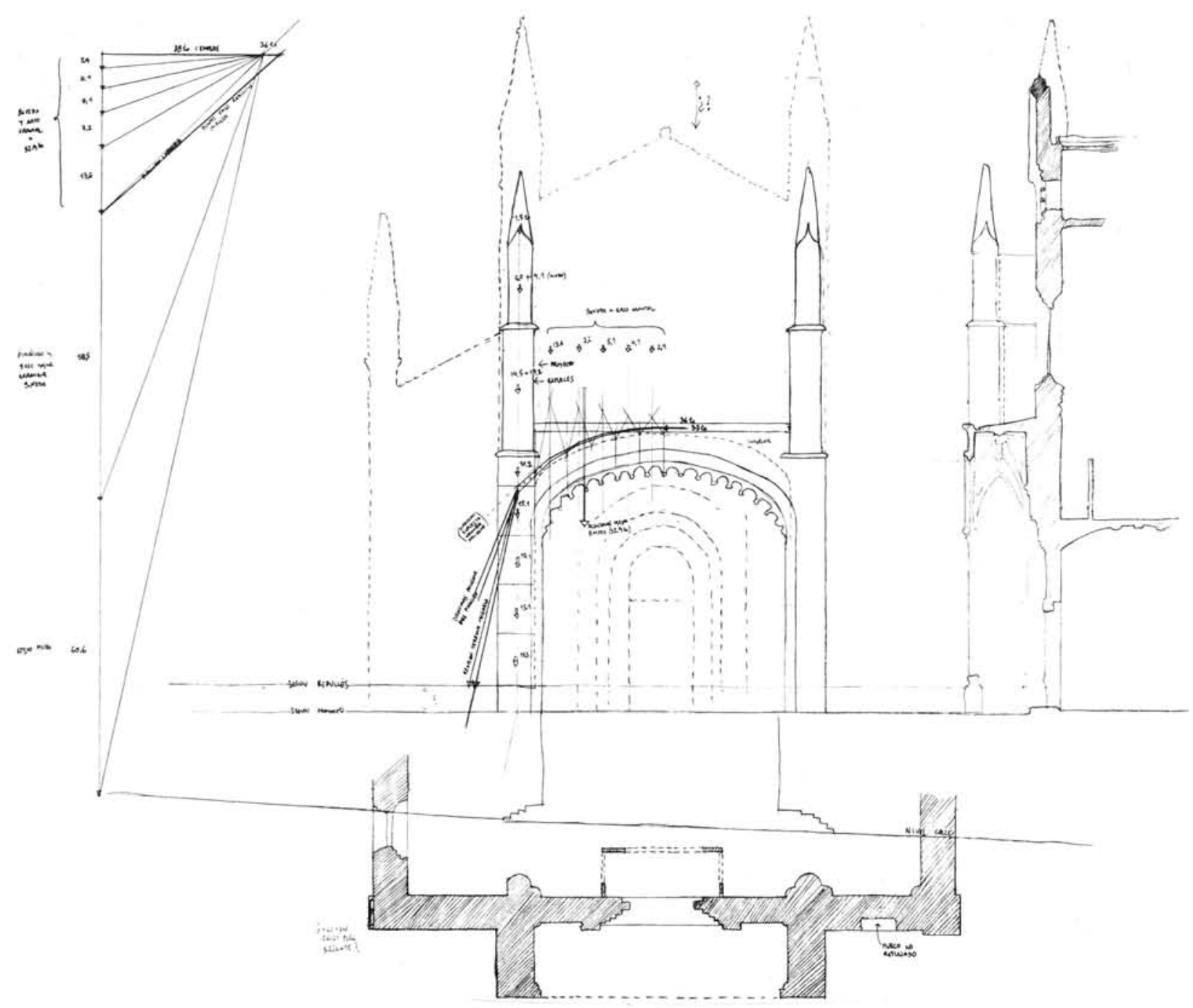

Cálculo gráfico de los empujes del arco carpanel de la entrada.

Por otro lado, unos elementales cálculos gráficos nos desvelan que el peso de los pináculos laterales no es suficiente para centrar el empuje del arco carpanel y la bóveda, para obligar a que la reacción entre en la base del apoyo. Necesariamente estaban las fábricas trabajando a cortadura, hasta que se ha producido la rotura de uno de los laterales al fallar la base.

Se procedió a micropilotar toda la zona de la portada, así como a realizar cosidos estáticos que traban las fábricas agrietadas y separadas, inyectando lechada de cemento a través de las perforaciones, que ha colmatado todo el interior de los paños perforados de modo que, al margen de la resistencia a tracción que suponen las armaduras introducidas en las fábricas, se ha mejorado sensiblemente la consistencia interior de las mismas, su solidez (ahora es pétrea) y su porosidad (interiormente casi nula).

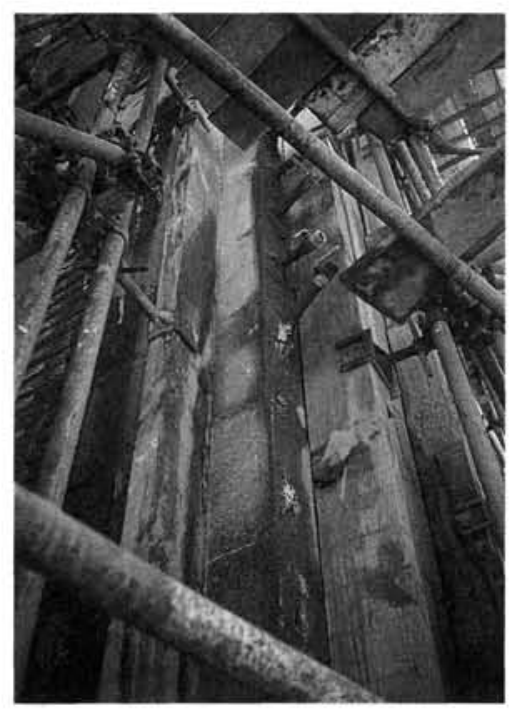

Perforaciones para los cosidos estáticos. Obsérvense las coquillas para la inyección de la lechada de cemento. 

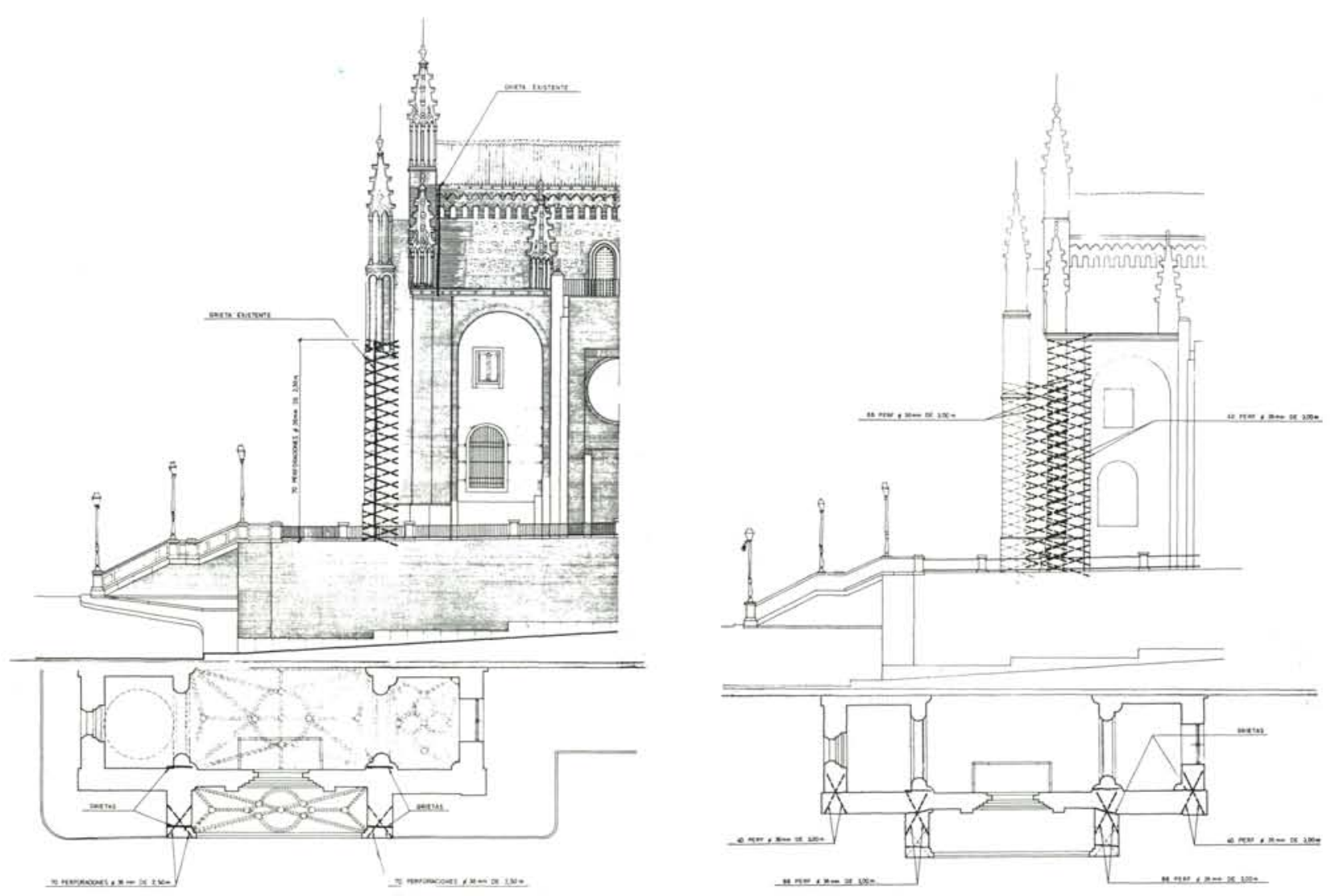

Cosidos estáticos efectuadce.

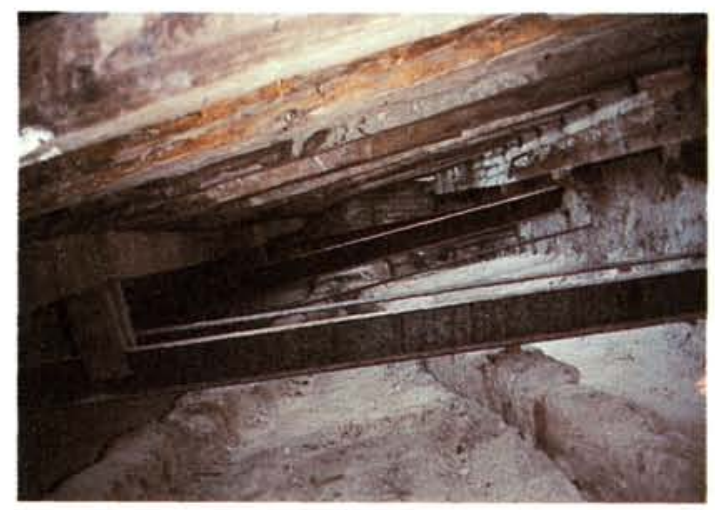

Interior de la bóveda de la entrada principal. Obsérvense los perfiles metálicos que existian.

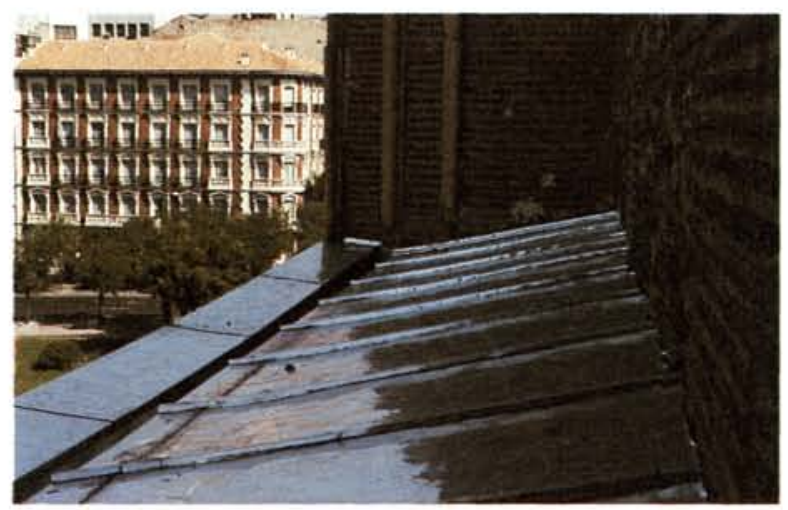

La cubierta de cinc sobre la bóveda de entrada prácticamente terminada.
La reparación de la bóveda, prácticamente desprendida, se ha realizado consolidándola in situ mediante un "encamisado" superior de lámina de hormigón. La bóveda es perforada cada $25 \mathrm{~cm}$ por un redondo de pequeño diámetro, quedando colgada de la lámina de $8 \mathrm{~cm}$ de espesor que, a su vez, se ancla en el muro de la portada y en una viga de hormigón armado. Esta viga elimina los empujes del arco, rigidiza el peto superior y transmite todas las cargas a los machones mediante anclajes metálicos inyectados.

La cubierta de esta anteportada se ha hecho de cinc. 


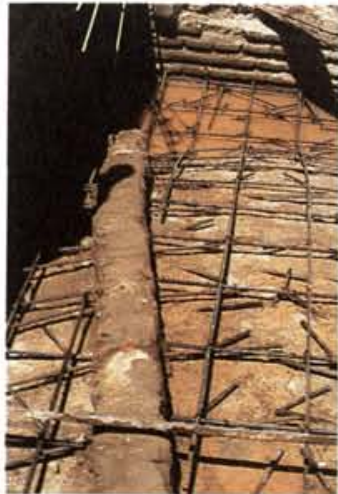

1

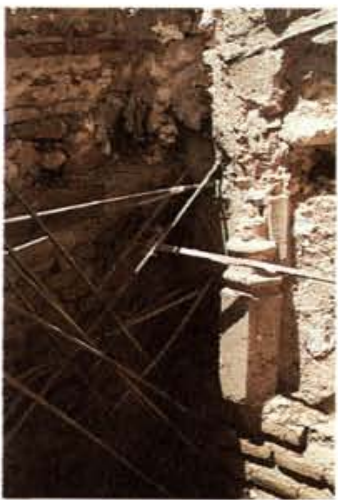

4

Si observamos la sección por un contrafuerte, podemos entender por qué se le inclinaban los pináculos a Repullés hacia dentro (estaban apoyados en parte sobre la estructura de madera de las cubiertas laterales) y lo que no podemos entender es cómo no se ha caído toda la fachada de la planta superior al no estar unida a los contrafuertes, sufrir el empuje de la cubierta y estar degollada por las bajantes que la cruzaban en diagonal y por los antiguos huecos mal tapados.

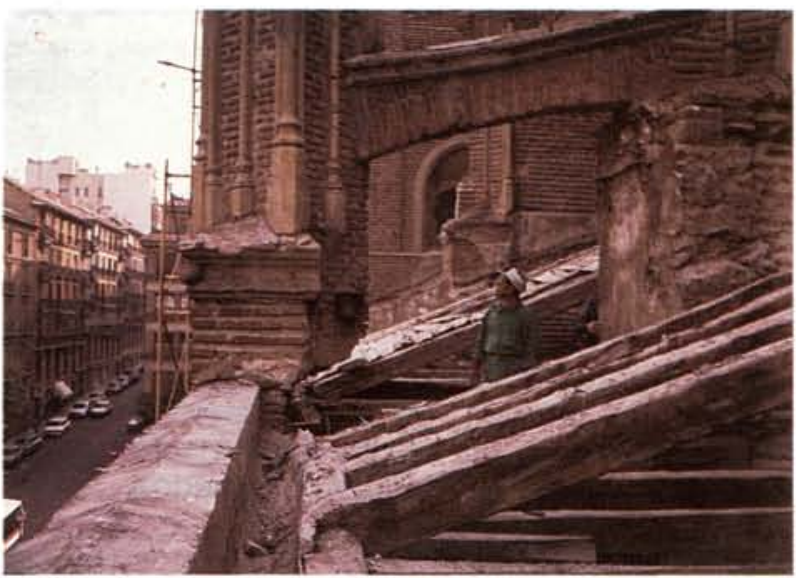

Cubierta de la fachada norte desmontada. Obsérvese la base de apoyo del pináculo.

(c) Consejo Superior de Investigaciones Científicas Licencia Creative Commons 3.0 España (by-nc)

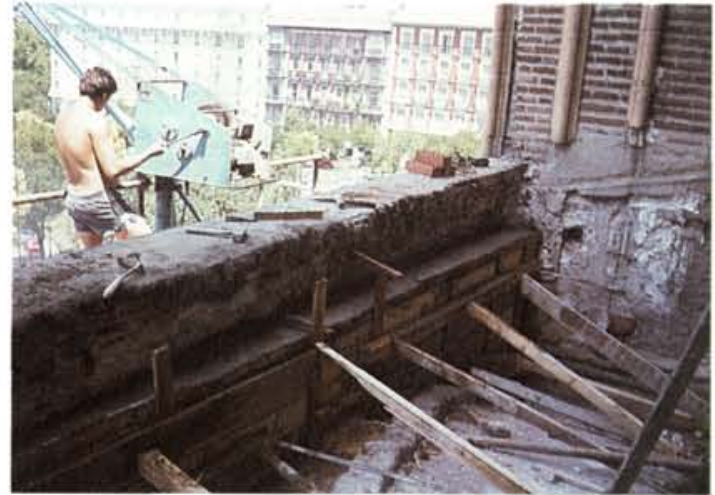

3

- Armadura de la lámina de hormigón, cosidos de la bóveda y redondos que atraviesan los nervios de la misma.

- La lámina de hormigón ya ejecutada y se va a comenza con la viga que trasdosa el arco y el peto (a la derecha).

3.- Encofrado de la viga que trasdosa el arco.

4. - Anclajes para apoyo y cuelgue de la viga de canto.

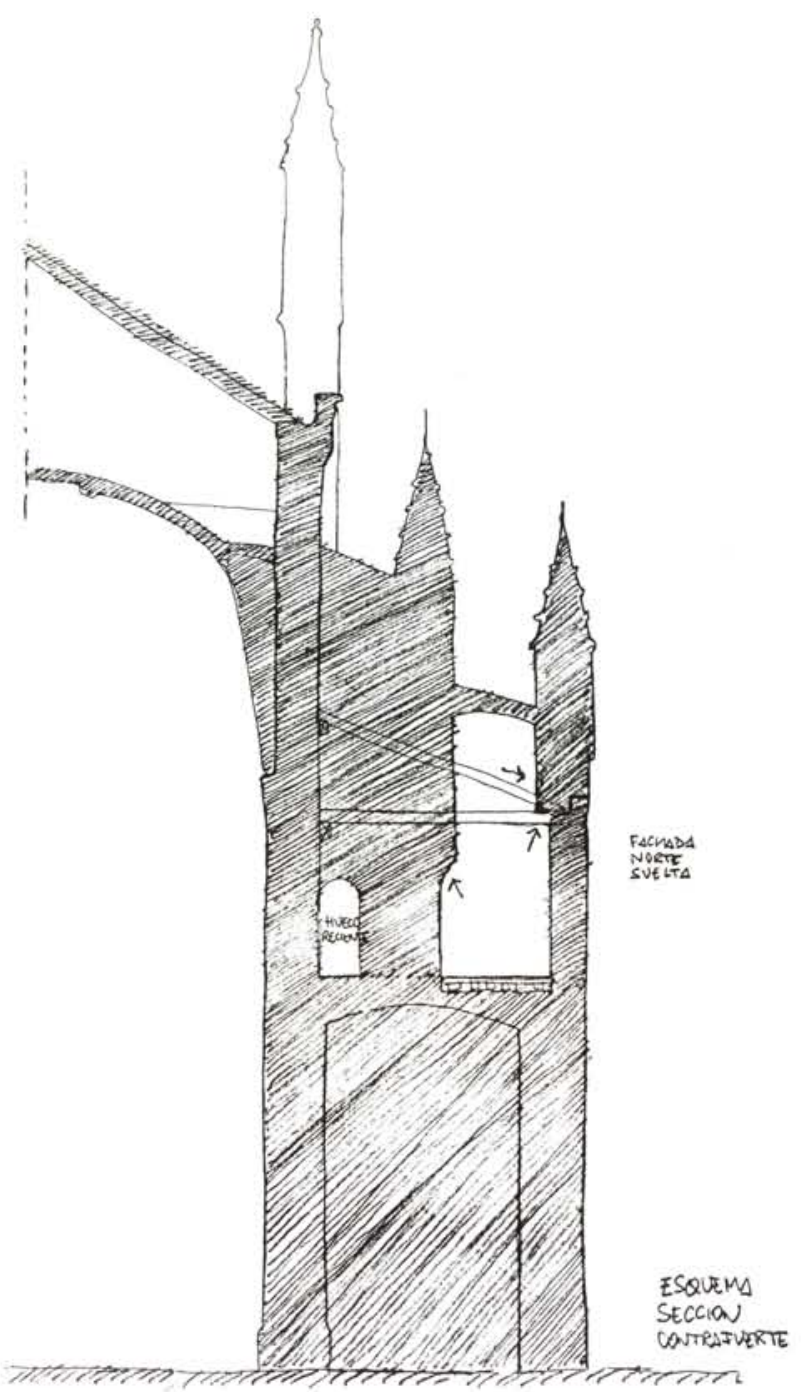

http://informesdelaconstruccion.revistas.csic.es 


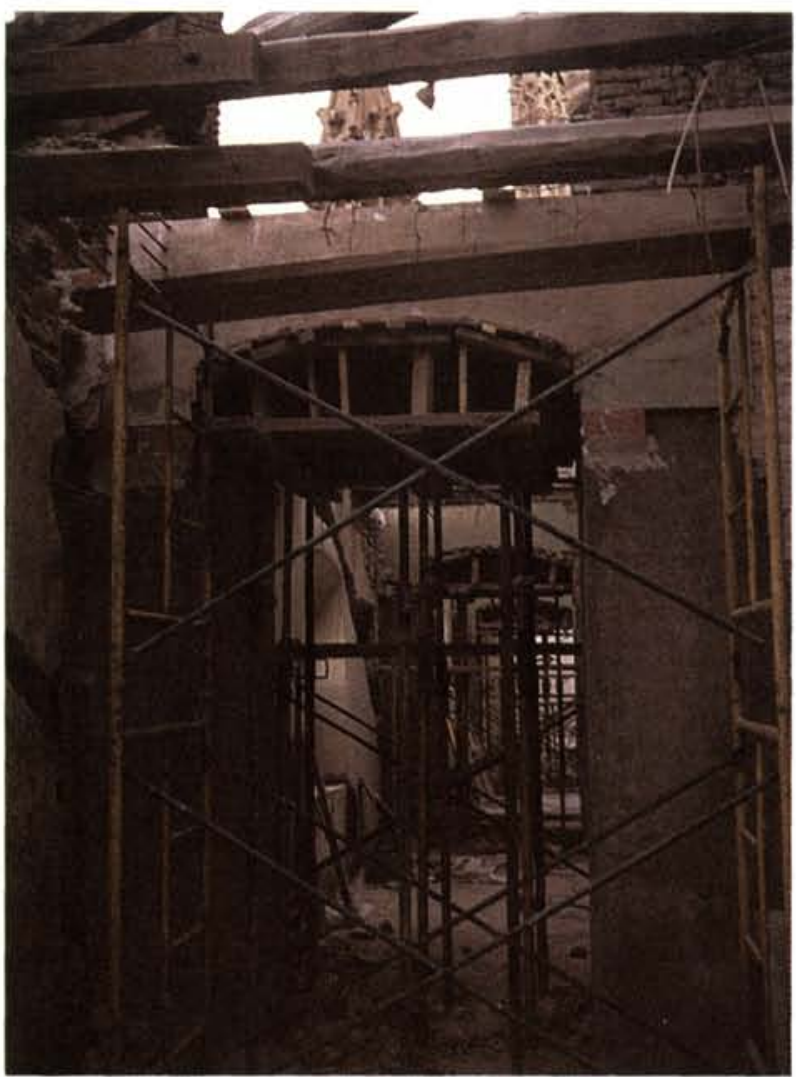

Porticos de hormigón en fase de ejecucion.

Se ha proyectado un pórtico de h.a. (con un dintel en arco rebajado) que continúa el contrafuerte interior hasta la fachada, en ambas capillas laterales (tiene anclajes en las fábricas de ladrillo). Estos pórticos recogen también los pináculos que antes descansaban sobre la madera de la cubierta.

Las cubiertas de las capillas laterales se apoyan ahora sobre un forjado plano que no produce empujes en los muros.

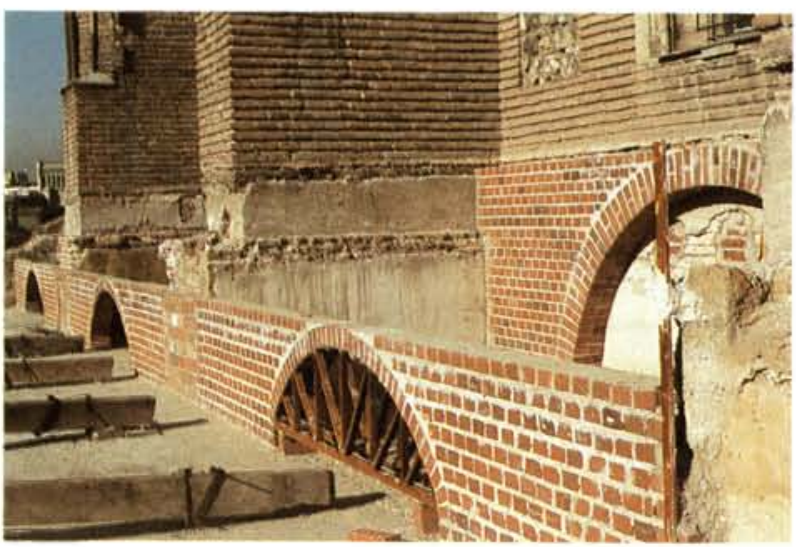

Arcos sobre el forjado de cubierta para apoyo de los faldones.

(c) Consejo Superior de Investigaciones Científicas Licencia Creative Commons 3.0 España (by-nc)

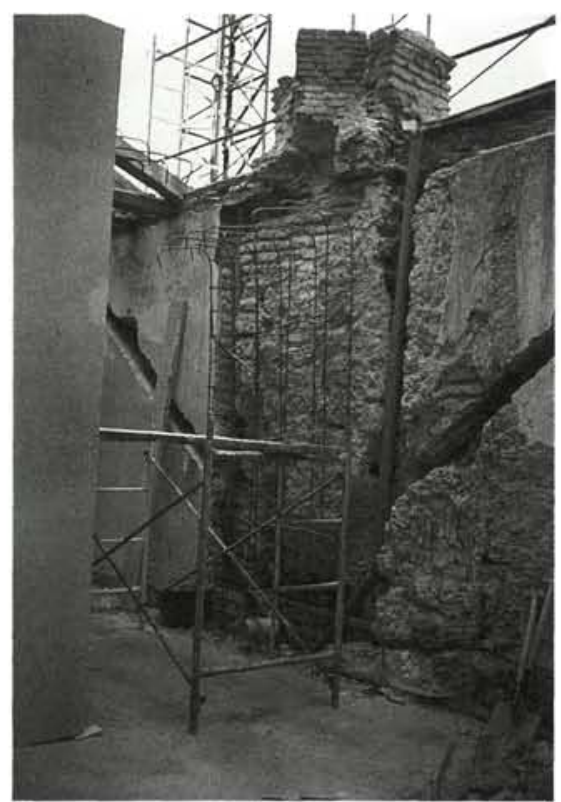

Nueva disposición de las bajantes a los lados del pórtico. Obsérvese el trazado inclinado anterior degollando el muro.

El faldón de las cubiertas se lleva a cabo reutilizando las maderas que existian anteriormente, después de cortar sus cabezas deterioradas, para lo que se disponen dos filas de arcos encima del forjado superior, sobre los que apoyan los pares de madera. Encima de los pares se asienta un tablero hidrófugo, al que se ha clavado una tela de gallinero y sobre el que se vierte una capa de compresión, futuro soporte de las tejas curvas.

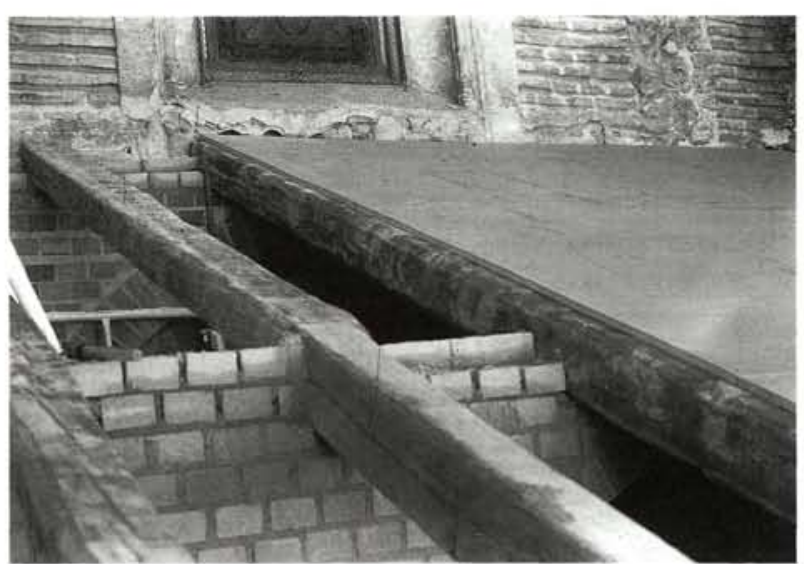

Formación del tablero de cubierta reutilizando las maderas anteriores y con tablero hidrófugo. 

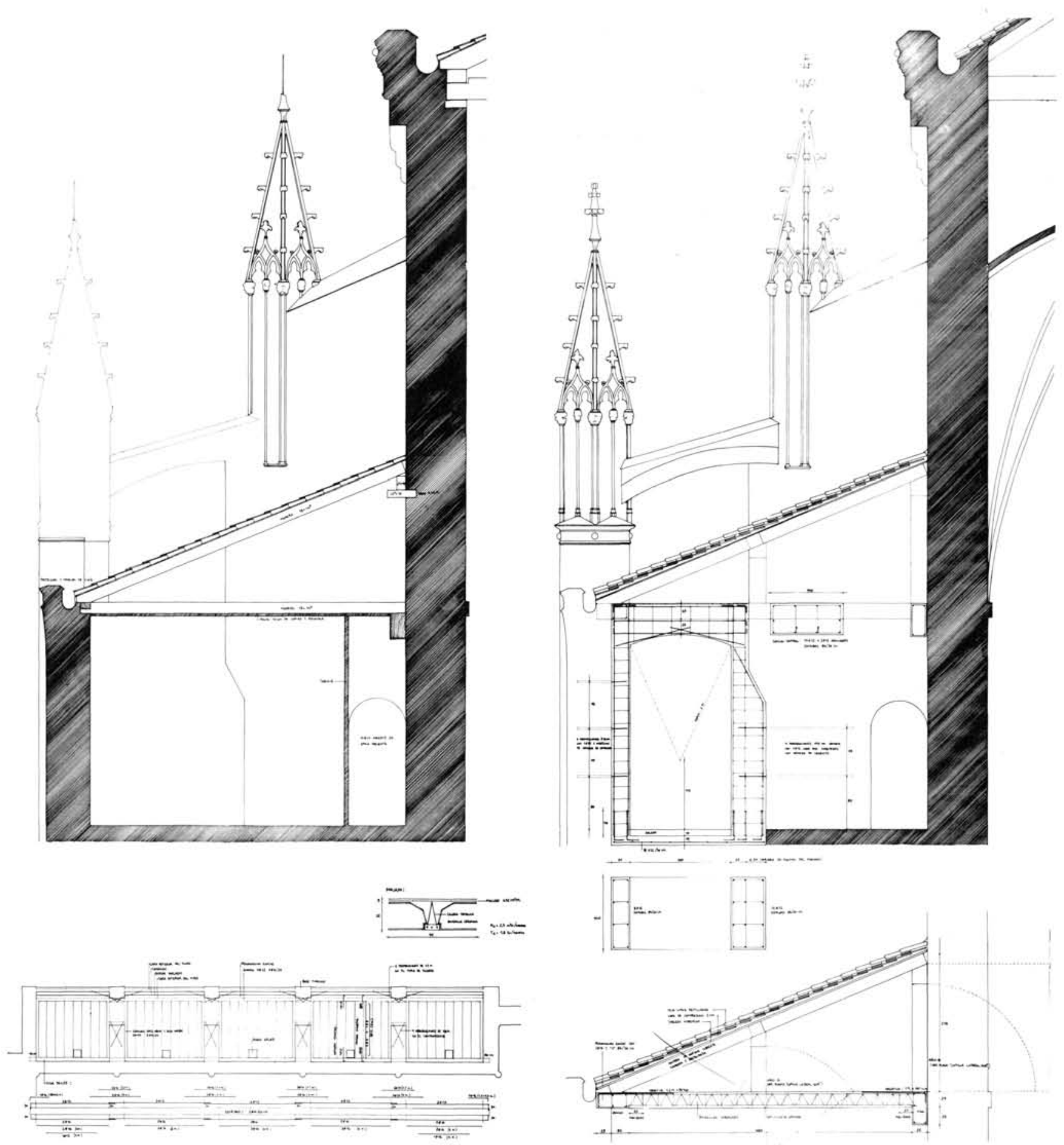

Plano del estado anterior y reparaciones en la fachada norte. 

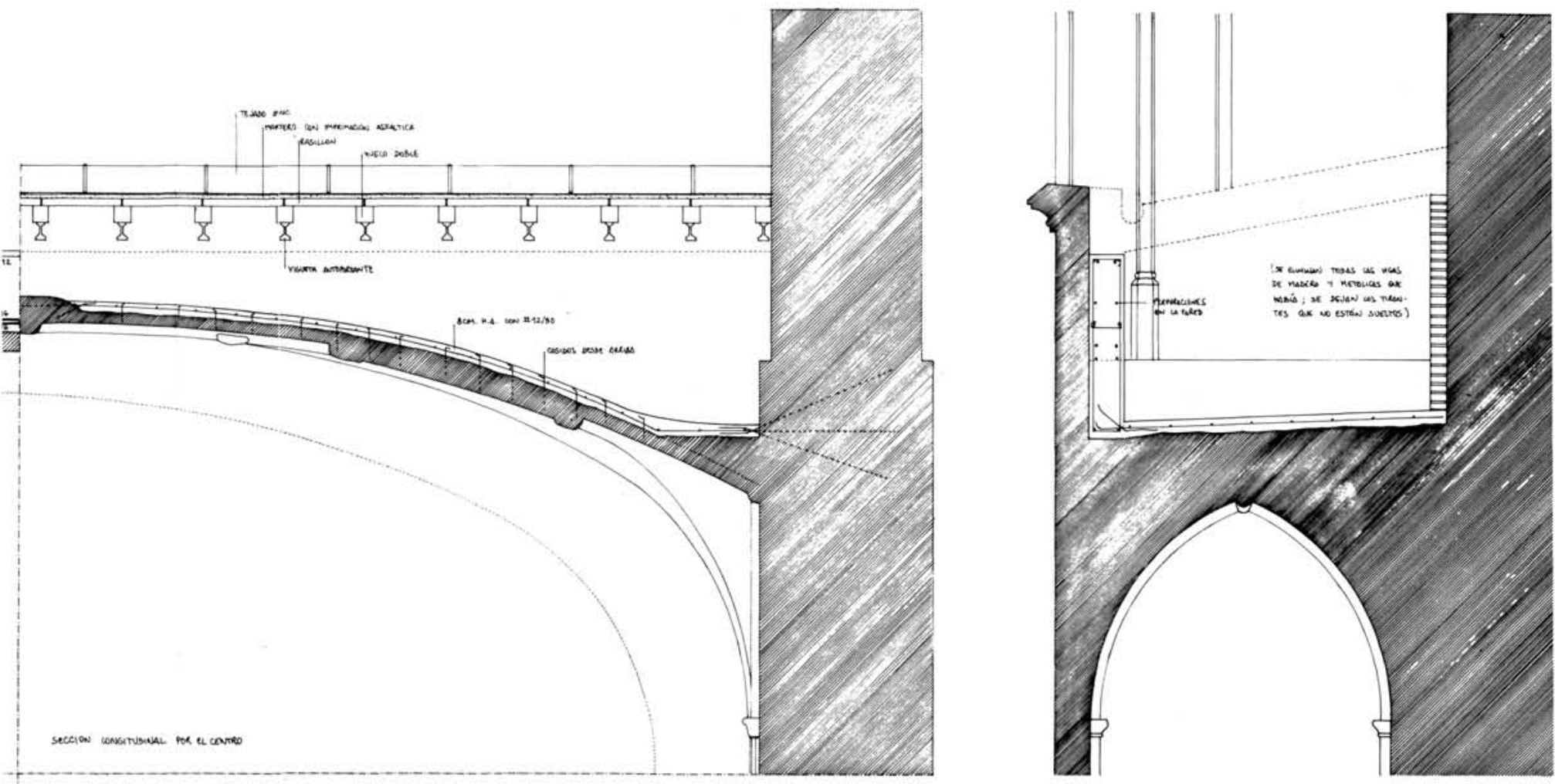

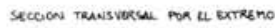
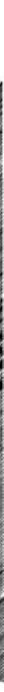

Plano para la reparación de la bóveda de la zona de ac 
Informes de la Construcción, Vol, 38, n॰387, enero/febrero, 1987
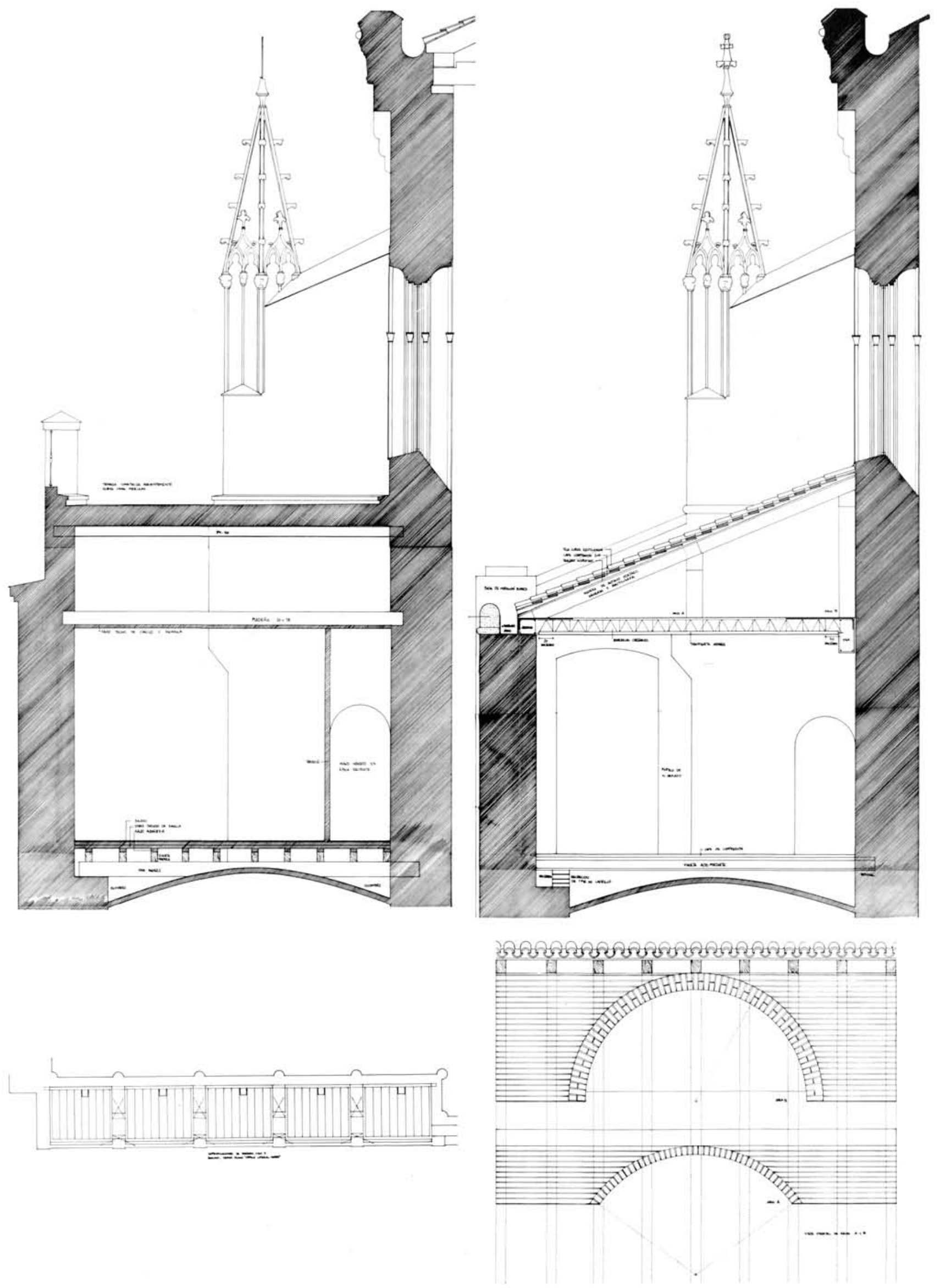

Plano del estado anterior y reparaciones en la fachada sur.

(c) Consejo Superior de Investigaciones Científicas

http://informesdelaconstruccion.revistas.csic.es Licencia Creative Commons 3.0 España (by-nc) 


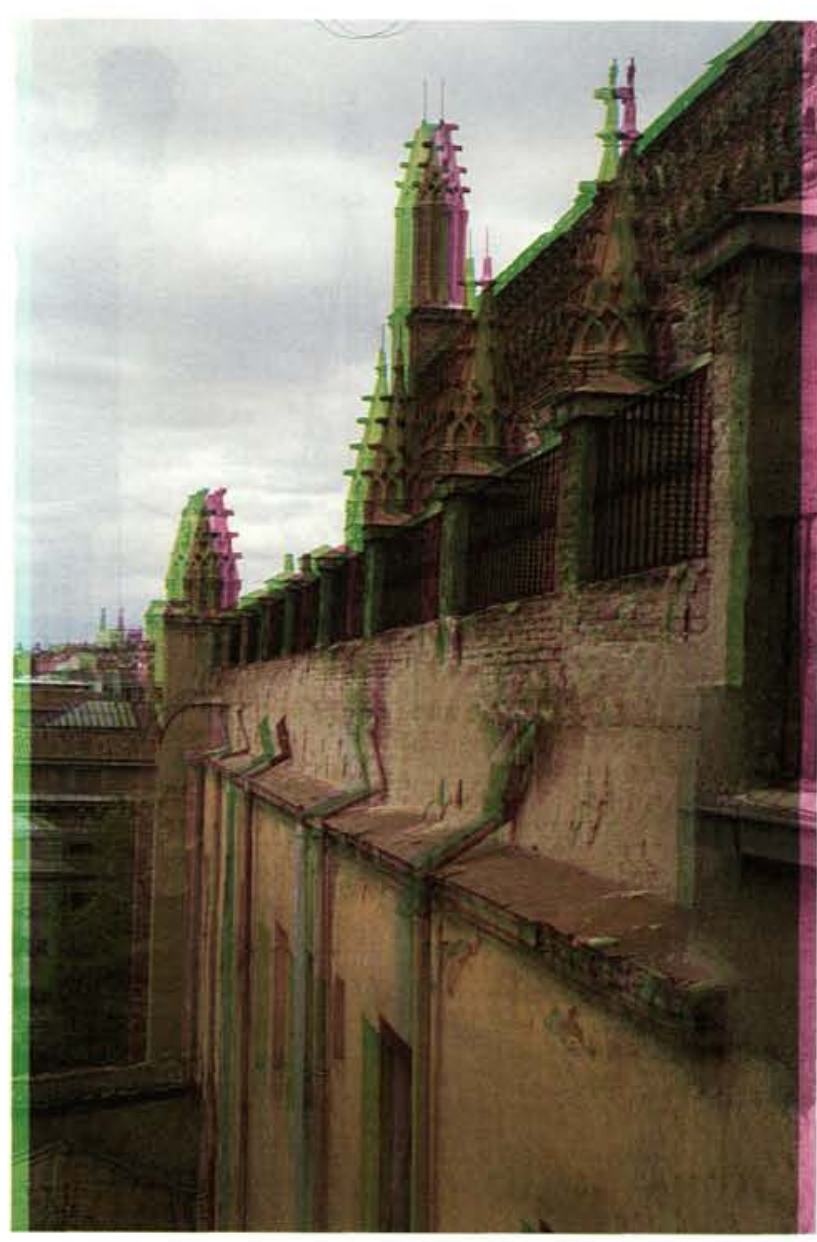

La cubierta plana que existia en la fachada sur. Obsérvese la traza del antiguo alero y la disposición aleatoria de los huecos de la fachada.

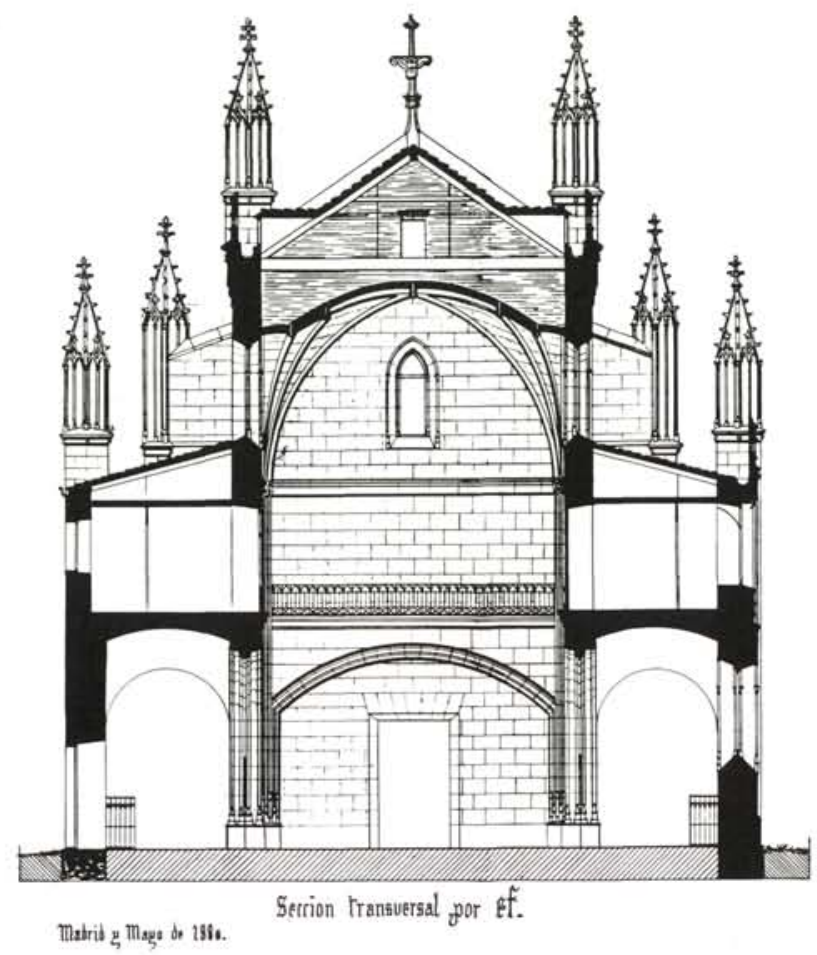

Dibujo de Repullés (1880) donde se observan las dos naves laterales con cubiertas inclinadas.

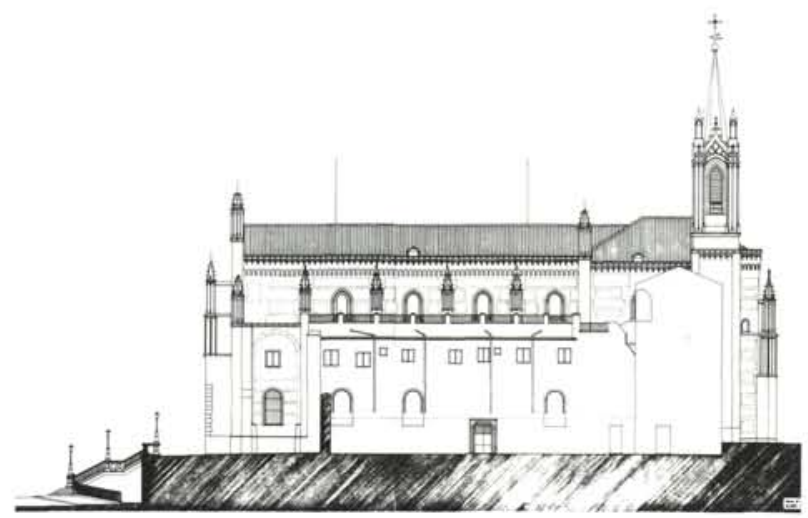

Alzado sur desde el claustro.

Se ha eliminado la cubierta plana, que ya en este siglo se había hecho en la fachada colindante con el claustro, volviendo a disponerla con su aspecto primitivo.

Paralelamente se ha restaurado todo el paramento, reordenando también todos los huecos superiores de esta fachada. El muro que la conforma interiormente está formado por trozos de tapial, trozos de derribos, huecos antiguos vueltos a tapar y, además, presentaba exteriormente un aumento de grosor debido al "doblado" que suponia un entramado de madera con relleno entre medias. Al introducir los nuevos huecos superiores a ejes con los inferiores se debilitaba aún más este muro, al tener que cortar en algunos casos el entramado. Se procedió a clavar oblícuamente redondos de acero.en el muro antiguo, después se colocó una tela de gallinero exterior y, posteriormente, se enfoscó (ante la imposibilidad de poder apoyar cualquier "forro" abajo, pues están las salas parroquiales), quedando la fachada también "encamisada" y precomprimida por este forro estructural.

Se mantiene el aspecto de revoco, puesto que ésta es la imagen que la iglesia poseía tras su restauración neogótica, a la que debe su actual imagen.

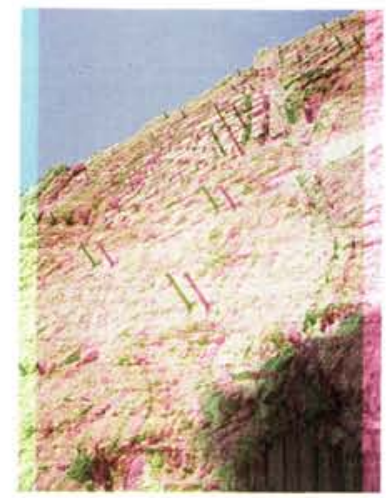

Reparacion de la fachada sur. Observense los redondos de acero clavados oblicuamente. 


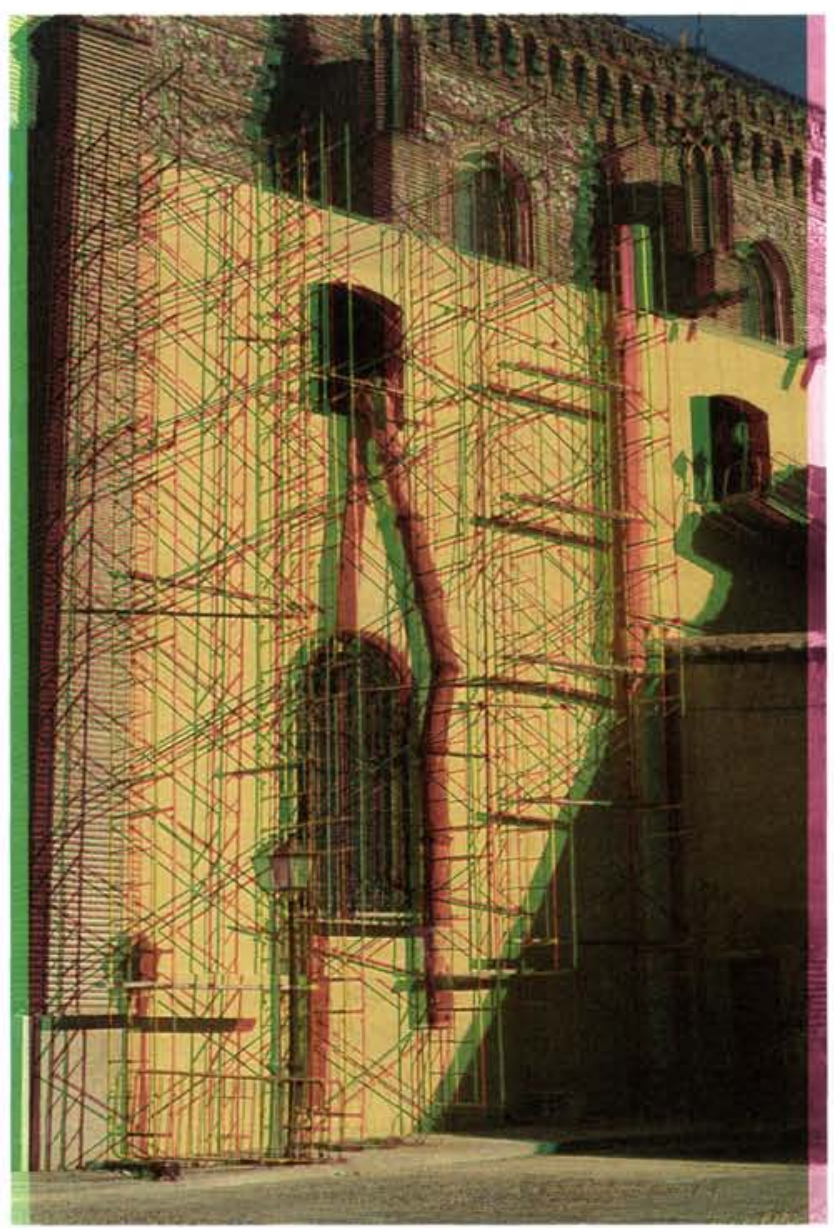

La fachada sur una vez consolidada (a falta aún de cornisas y remates superiores) con los nuevos huecos superiores a ejes con los inferiores. Foto reciente (enero 1987).

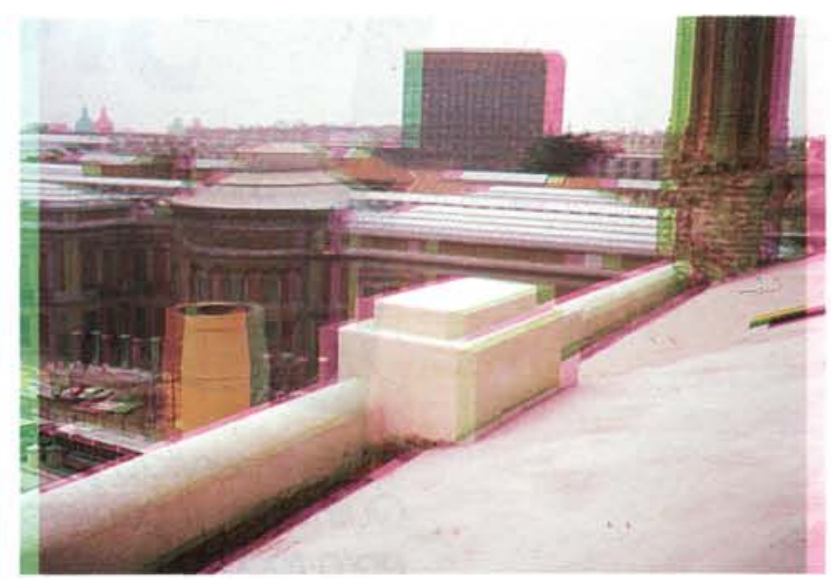

Basa y cornisa nuevas en la fachada sur (abril 1987).

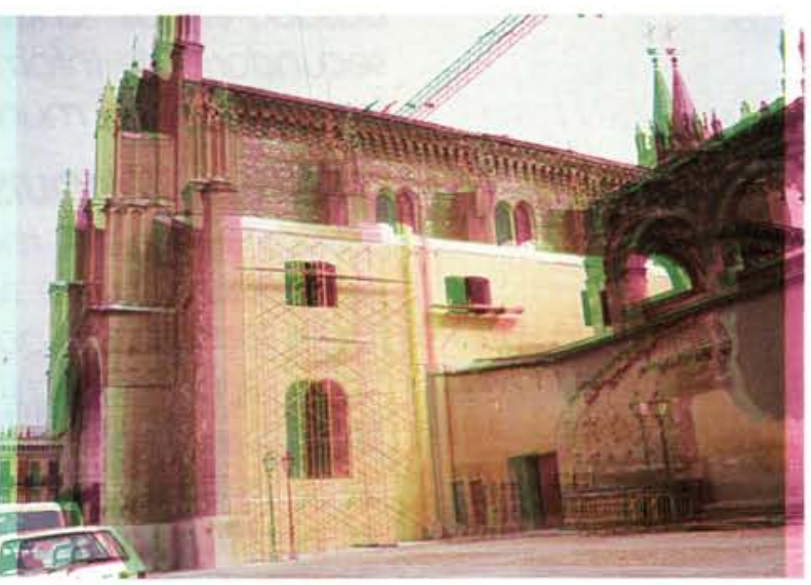

Fachada sur con la nueva cornisa recién ejecutada (abril 1987).

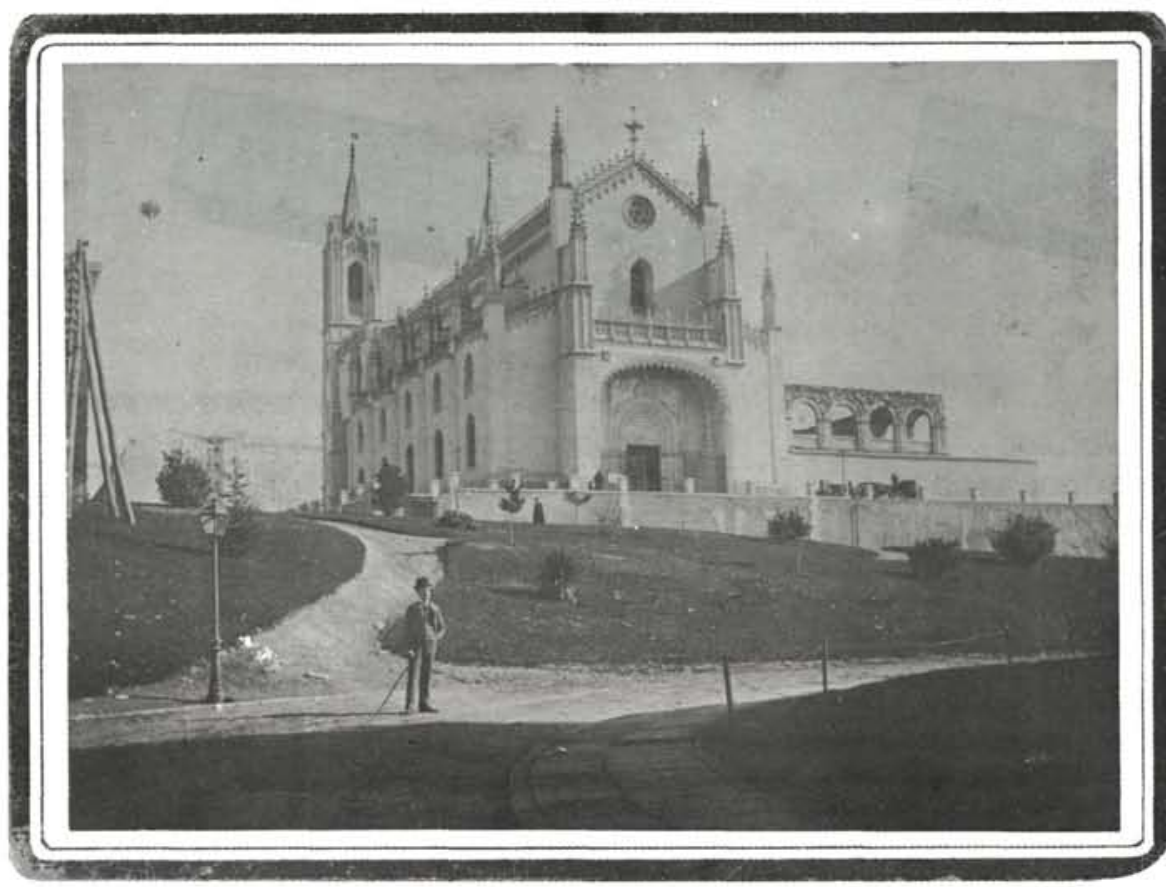

La iglesia recién restaurada por Repullés (fotografia 1900?); aún no existe la escalinata abierta para las bodas de Alfonso XIII.

Este es el aspecto de la iglesia revocada buscado en nuestra restauración.
Las obras están en fase de ejecución y aún hay muchos temas por abordar en sucesivas actuaciones: cubierta superior de la nave principal, torres, claustro, galerías subterráneas, etcétera. 